\title{
PERANCANGAN KONTEN E-LEARNING PADA KEGIATAN PEMBUATAN DAN PEMASANGAN KUBAH MASJID DI PERUSAHAAN TIGA BERLIAN MENGGUNAKAN METODE SECI DAN ADDIE
}

\author{
Bima Dwica Ananto, Amelia Kurniawati*, Afrin Fauzya Rizana, Nurdinintya Athari \\ Supratman
}

Program Studi Teknik Industri, Fakultas Rekayasa Industri, Universitas Telkom, Jl. Telekomunikasi, Terusan Buah Batu, Sukapura, Bandung, Indonesia 40287

(Received: March 9, 2021/Accepted: June 9, 2021)

\begin{abstract}
Abstrak
Dalam suatu organisasi atau perusahaan, knowledge merupakan aset yang sangat dibutuhkan ketika melakukan kegiatan kerja maupun untuk pengembangan bisnis organisasi atau perusahaan. Salah satu contohnya adalah perusahaan Tiga Berlian yang bergerak di bidang kontruksi baja berat dan ringan seperti teralis, pagar besi dan pembuatan kubah masjid. Salah satu contoh knowledge merupakan asset bagi perusahaan adalah ketika kegiatan pembuatan dan pemasangan kubah masjid terdapat tacit knowledge yaitu dalam penentuan ukuran jarak antar bahan yang akan dipasang. Oleh karena itu, dalam penelitian ini dirancang media pembelajaran berbasis e-learning yang bertujuan untuk melakukan dokumentasi tacit knowledge yang ada sehingga dapat digunakan oleh pekerja lain untuk pembelajaran cara pembuatan dan pemasangan kubah masjid. Penelitian ini dirancang menggunakan metode ADDIE dan metode SECI. Setelah melakukan pengumpulan dan pengolahan data, terdapat 6 kegiatan pembuatan dan pemasangan kubah masjid yaitu pembuatan kerangka, pemasangan kerangka, pembuatan daun kubah, pemasangan daun kubah dan aluminum foil, pembuatan plafon, dan pemasangan plafon. Pada media e-learning tidak hanya terdapat konten 6 kegiatan pembuatan dan pemasangan kubah masjid, tetapi terdapat juga bahan yang digunakan, alat yang digunakan, dan kuis untuk proses evaluasi pemahaman materi mengenai kegiatan dan pemasangan kubah masjid.
\end{abstract}

Kata kunci: ADDIE, e-learning; knowledge; SECI; tacit knowledge

\begin{abstract}
[Design of E-Learning Content On The Making And Installing of Mosque Domes In Tiga Berlian Companies Using Seci And Addie Methods] In an organization, knowledge is an asset that is needed when carrying out work activities or for developing an organization's or company business. There are many knowledges that are not explicitly documented in Tiga Berlian Company. Therefore, in this study, e-learning based learning media was designed to document existing tacit knowledge so that other workers can use it to learn how to make and install mosque domes. This study was designed using the ADDIE method and the SECI method. After collecting and processing data, there were 6 activities for making and installing a mosque dome, namely making the frame, installing the frame, making the dome leaves, installing the dome and aluminum foil, making the ceiling, and installing the ceiling. In the $e$ learning media, there is not only the content of 6 activities for making and installing mosque domes, but there are also materials used, tools used, and quizzes for the evaluation process of understanding material regarding activities and installing mosque domes.
\end{abstract}

Keywords: ADDIE; e-learning; knowledge; SECI; tacit knowledge

\footnotetext{
*Penulis Korespondensi.

E-mail: ameliakurniawati@telkomuniversity.ac.id
}

\section{Pendahuluan}

Dalam suatu organisasi, knowledge merupakan sala satu asset penting untuk dapat tetap kompetitif di lingkungan bisnis dan dipandang sebagai sumber strategis bagi organisasi (Xue, 2017). Maka dari itu, penting bagi perusahaan untuk memahami bagaimana 
knowledge terbentuk, disebarkan, dan diaplikasikan di dalam organisasi (Xue, 2017). Tanpa pengelolaan yang baik, knowledge yang terdapat di perusahaan dapat menjadi usang dan tidak berguna lagi.

Knowledge memiliki 2 jenis bentuk yaitu tacit knowledge dan explicit knowledge. Tacit knowledge merupakan knowledge yang berasal dari kumpulan pengalaman seseorang yang berada di dalam pikiran individu dalam organisasi dan sulit untuk dibagikan kepada orang lain (Iskandar \& Subekan, 2018). Dilaporkan bahwa $90 \%$ knowledge yang dimiliki oleh organisasi tertanam dan disintesa di pikiran para pegawainya. Tacit knowledge dapat hilang melalui outsourcing, downsizing, merger dan pemberhentian kerja (Smith, 2001). Explicit knowledge merupakan knowledge yang dapat untuk didokumentasikan, diartikan, dan dibagikan kepada orang lain. Explicit knowledge biasanya disimpan dalam bentuk dokumen, web, dan e-learning (Kusumastuti, Soesanto, Kurniawati, \& Kurniawan, 2020).

Tacit knowledge yang dimiliki oleh pekerja sangat dibutuhkan dalam kelancaran proses bisnis perusahaan. Penting bagi perusahaan untuk membuat knowledge yang dimiliki oleh individu menjadi knowledge organisasi. Oleh sebab itu, perusahaan perlu lebih efektif dalam mempertahankan tacit knowledge dan membuatnya dapat diakses oleh pegawai lain, sehingga penting bagi perusahan untuk melakukan proses konversi tacit knowledge menjadi explicit knowledge merupakan hal kritis (Battistuti \& Bork, 2017; Gaghman, 2019).

Permasalahan terkait bagaimana mempertahankan knowledge pun dialami oleh Perusahaan Tiga Berlian. Perusahaan Tiga Berlian adalah perusahaan yang bergerak di bidang kontruksi khususnya sebagai kontraktor, supplier dan aplikator baja ringan, baja berat, aluminum composite panel, dan kubah masjid. Berdasarkan hasil wawancara, permasalahan yang terdapat di perusahaan adalah pada setiap proses kegiatan hanya terdapat satu pekerja yang familiar dan ahli dalam masing-masing pekerjaan. Hal tersebut memunculkan risiko perusahaan akan kehilangan knowledge ketika pegawai tersebut tidak lagi bekerja di perusahaan. Perginya pegawai yang memiliki knowledge yang dimiliki pegawai ahli tersebut akan ikut dibawa oleh pegawai tersebut, dan perusahaan akan kehilangan asset berharganya, yaitu knowledge terkait best practice dalam melakukan pengerjaan tertentu. Maka dari itu, knowledge terkait best practice penyelesaian suatu aktivitas yang dimiliki oleh pegawai perlu dikonversi menjadi explicit knowledge, sehingga knowledge tersebut dapat diakses oleh pegawai lain saat dibutuhkan.

Salah satu contoh knowledge yang belum sepenuhnya terdokumentasi dan masih menjadi tacit knowledge adalah knowledge yang dimiliki pegawai yang bertugas dalam pembuatan dan pemasangan kubah masjid. Proses knowledge sharing yang terjadi saat ini pada perusahaan masih terbatas pada aktivitas diskusi dan juga pemberian instruksi secara langsung.
Saat pegawai ahli tidak hadir dalam proses pembuatan produk, proses pembuatan produk menjadi terhambat karena minimnya knowledge pegawai lainnya dalam melakukan proses tersebut.

Maka dari itu knowledge yang dimiliki oleh ahli perlu dikonversi menjadi explicit knowledge untuk kemudian disimpan dalam suatu media penyimpanan yang dapat diakses dan dipelajari oleh pegawai lainnya. Salah satu bentuk media penyimpanan knowledge yang sekaligus dapat digunakan sebagai media pembelajaran pegawai adalah e-learning. E-learning atau electronic learning didefinisikan sebagai penggunaan Teknologi Informasi dan Komunikasi, serta komputer untuk memberikan instruksi, informasi, dan konten pembelajaran (Bhuasiri et al., 2012).

Penggunaan dokumentasi e-learning memiliki banyak keunggulan, seperti memudahkan pekerja belajar dengan adanya video dan gambar sehingga pekerja dapat memahami knowledge secara individu tanpa perlu adanya bantuan dari orang lain (Jefri et al., 2018). Lebih lanjut, penerapan e-learning dapat membuat pemberian konten lebih fleksibel, konten yang diberikan dapat lebih terstandarisasi, dan juga setiap individu dapat mengakses materi belajar yang sesuai dengan kebutuhannya (Bhuasiri et al., 2012; Rizana et al., 2020).

Oleh karena itu, penelitian ini memiliki tujuan untuk merancang konten $e$-learning yang berisikan best practice dalam aktivitas pembuatan dan pemasangan kubah masjid. E-learning yang dirancang perlu memiliki konten yang baik dan disesuaikan dengan kebutuan penggunanya (Adeyinka \& Mutula, 2010). Melalui perancangan e-learning, knowledge yang dimiliki oleh setiap pekerja dapat didokumentasikan, sehingga bisa digunakan sebagai bahan belajar bagi pekerja yang lain.

Model ADDIE merupakan salah satu metode yang popular digunakan dalam perancangan $e$ learning. Model ADDIE terdiri dari lima tahap yaitu analyze, design, development, implementation, dan evaluation (Wiphasith, Narumol, \& Sumalee, 2016). Beberapa penelitian terdahulu menggunakan metode ADDIE dalam perancangan e-learning (Wiphasith, Narumol, \& Sumalee, 2016). Model ADDIE memberikan proses sistematis dalam perancangan $e$ learning mulai dari tahap melakukan identifikasi kebutuhan hingga evaluasi hasil belajar pengguna melalui e-learning yang dirancang. Maka dari itu, model ADDIE dirasa cocok untuk diterapkan dalam proses prancangan e-learning dalam penelitian ini. Namun demikian, karena pada penelitian ini konten $e$ learning akan didasari oleh best practice proses pembuatan dan pemasangan kubah masjid berdasarkan tacit knowledge pegawai ahli, maka perlu dilakukan konversi knowledge. Proses konversi knowledge dapa dilakukan dengan menggunakan metode SECI yang terdiri dari Socialization, Externalization, Combination dan Internalization. Penggunaan metode SECI pada proses konversi knowledge didasari oleh pertimbangan bahwa data yang digunakan merupakan tacit 
knowledge pekerja dan pemilik perusahaan. Beberapa penelitian terdahulu telah berhasil mengintegrasikan SECI ke dalam model ADDIE Penggunaan metode ADDIE bertujuan untuk merancang e-learning karena metode ADDIE lebih sistematis dan terstruktur dalam melakukan proses evaluasi dan proses pembelajaran (Allen, 2006). Diharapkan dengan adanya perancangan e-learning untuk pembuatan dan pemasangan kubah masjid dapat membantu proses bisnis perusahaan.

\section{Metode Penelitian}

Penelitian ini bertujuan untuk merancang konten e-learning untuk aktivitas pembuatan dan pemasangan kubah masjid. Perancangan e-learning pada penelitian ini mengikuti tahapan pada metode ADDIE, yaitu analyze, design, development, implementation, dan evaluation. Lebih lanjut, pada penelitian ini pun menggunakan model SECI untuk melakukan knowledge conversion sebagai upaya untuk memperoleh best practice dari aktivitas pembuatan dan pemasangan kubah masjid. Best practice tersebut kemudian digunakan sebagai dasar dalam perancangan konten e-learning pada tahap design.

\subsection{ADDIE}

Terdapat beberapa tahapan pada metode ADDIE, yaitu tahap analyze, design, development, implementation, dan evaluation (Whipasith, et al., 2016).

\section{A. Analyze}

Tahap analyze adalah tahap meneliti cara karyawan mempelajari proses kegiatan pembuatan dan pemasangan kubah masjid saat ini dan meneliti kebutuhan perusahaan untuk menunjang pembelajaran kegiatan pembuatan dan pemasangan kubah masjid. Identifikasi kebutuhan perusahaan dilakukan melalui wawancara. Wawancara dilakukan kepada 2 orang pekerja yang telah terbiasa melakukan kegiatan pembuatan dan pemasangan kubah masjid.

\section{B. Design}

Pada tahap ini, dilakukan perancangan mengenai konsep dan juga konten untuk e-learning. Proses perancangan ini dilakukan dengan mengidentifikasi best practice pemasangan kubah masjid berdasarkan pengalaman pekerja. Proses identifikasi tersebut dilakukan dengan cara mengumpulkan tacit knowledge para pekerja untuk kemudian dikonversi dan digunakan sebagai panduan dalam merancang konten e-learning. Proses konversi tacit knowledge pemasangan kubah masjid dilakukan dengan menggunakan SECI yang terdiri dari tahap socialization, externalization, combination, dan internalization. Pada metode SECI dilakukan aktivitas konversi pengetahuan dari tacit knowledge menjadi explicit knowledge dengan menggunakan beberapa tahapan yaitu Socialization, Externalization, Combination, dan Internalization (Nonaka, 1991).

\section{1) Socialization}

Socialization merupakan kegiatan dalam melakukan sosialisasi kepada pekerja berupa tacit knowledge yang didapatkan dari pengalaman yang dari seseorang. Pada penelitian ini, tahap socialization dengan cara mewawancarai pekerja dan ahli mengenai pembuatan dan pemasangan kubah masjid, wawancara juga ditujukan untuk mendapatkan tacit knowledge yang dimiliki oleh pekerja dan ahli. Tacit knowledge yang didapatkan akan dijadikan sebagai panduan untuk membuat konten e-learning pembuatan dan pemasangan kubah masjid.

2) Externalization

Externalization merupakan kegiatan melakukan transfer pengetahuan dari tacit knowledge menjadi explicit knowledge dengan cara diskusi antar pekerja sehingga satu sama lain saling berbagi pengetahuan dan menciptakan tacit knowledge yang baru. Tacit knowledge dari diskusi antar pekerja belum terdapat dokumentasi knowledge yang membuat tacit knowledge hanya sebatas diskusi, oleh karena itu diperlukan dokumentasi terhadap tacit knowledge.

3) Combination

Combination merupakan kegiatan proses mengumpulkan, menyatukan, dan mengintegrasikan knowledge yang terdapat pada seseorang ke dalam knowledge system. Melakukan pengumpulan knowledge dari seseorang dengan pegalaman yang berbeda-beda membuat banyak pilihan knowledge untuk menyelesaikan masalah.

4) Internalization

Internalization merupakan kegiatan melakukan pengubahan dari explicit knowledge menjadi tacit knowledge.

\section{Development}

Setelah mendapatkan data dari tahap design, dilanjutkan ke tahap development untuk perancangan e-learning menggunakan storyboard berupa gambar sketsa yang memberikan gambaran awal pembuatan $e$ learning. Selanjutnya dilakukan pembuatan $e$ learning menggunakan software Adobe Flash Professional CS6, dan untuk penggunaan e-learning dibantu menggunakan software Adobe Flash Player 11.

\section{Implementation}

Tahap implementation dilakukan dengan melakukan percobaan penggunaan e-learning kepada pekerja untuk mengenalkan konten e-learning yang telah dirancang. Pada penelitian ini tahap implementation berfokus pada percobaan penggunaan e-learning kepada pekerja untuk mengenalkan konten e-learning yang telah dirancang dan melakukan pengujian penggunaan konten e-learning kepada pengguna. Pengujian yang dilakukan yaitu uji fungsionalitas sistem dan user acceptance test.

1) Uji fungsionalitas sistem 
Tabel 1. Rangkuman Proses Pembelajaran Pekerja Saat Ini

\begin{tabular}{cll}
\hline No & \multicolumn{1}{c}{ Pekerja } & \multicolumn{1}{c}{ Voice of Customer (VOC) } \\
\hline 1 & $\begin{array}{l}\text { Pembuatan dan pemasangan kubah masjid belum memiliki standar } \\
\text { pengerjaan. }\end{array}$ & $\begin{array}{l}\text { Perlu adanya SOP atau standar untuk } \\
\text { kegiatan pembuatan dan pemasangan } \\
\text { kubah masjid. }\end{array}$ \\
2 & $\begin{array}{l}\text { Setiap pekerja melakukan pembuatan dan pemasangan kubah masjid } \\
\text { dengan cara yang berbeda-beda. }\end{array}$ \\
3 & $\begin{array}{l}\text { Belum adanya panduan yang secara tertulis berupa dokumen untuk } \\
\text { proses pembelajaran. } \\
\text { Pembelajaran pembuatan dan pemasangan kubah masjid } \\
\text { dipraktikkan langsung oleh ahli. }\end{array}$ & $\begin{array}{l}\text { Perlu adanya media pembelajaran } \\
\text { pemasangan kubah masjid. }\end{array}$ \\
\hline
\end{tabular}

Tabel 2. Hasil Identifikasi Kebutuhan Perusahaan

\begin{tabular}{|c|c|c|}
\hline No & Pekerja & Voice of Customer (VOC) \\
\hline 1 & $\begin{array}{l}\text { e-learning menampilkan cara pembuatan dan pemasangan } \\
\text { kubah masjid. }\end{array}$ & $\begin{array}{l}\text { e-learning menampilkan informasi pembuatan dan } \\
\text { pemasangan kubah masjid dengan lengkap atau detail. }\end{array}$ \\
\hline 2 & e-learning tidak hanya berupa tulisan saja. & e-learning menampilkan tulisan dan gambar. \\
\hline 3 & e-learning mudah dimengerti pengguna. & e-learning mudah untuk digunakan. \\
\hline 4 & $\begin{array}{l}\text { e-learning menampilkan keseluruhan informasi kegiatan } \\
\text { pembuatan dan pemasangan kubah masjid. }\end{array}$ & $\begin{array}{l}\text { e-learning menampilkan informasi yang dapat } \\
\text { dipercaya untuk digunakan. }\end{array}$ \\
\hline 5 & e-learning tidak menggunakan internet. & e-learning digunakan dengan offline. \\
\hline
\end{tabular}

Uji fungsionalitas sistem dilakukan untuk memeriksa apakah e-learning berfungsi dengan baik. Pada penelitian ini uji fungsionalitas dilakukan terhadap kemampuan sistem e-learning dalam:

- Menampilkan bagian yang dapat mengakses alur proses, bahan, alat, dan kuis.

- Menampilkan bagian alur proses pembuatan dan pemasangan kubah masjid.

- Menampilkan informasi bahan yang digunakan untuk pembuatan dan pemasangan kubah masjid

- Menampilkan informasi alat yang akan digunakan untuk pembuatan dan pemasangan kubah masjid

- Menampilkan kuis dari setiap kegiatan untuk menguji kompetensi pekerja.

2) User acceptance test

User acceptance test (UAT) dilakukan untuk mengetahui kualitas e-learning kegiatan pembuatan dan pemasangan kubah masjid yang telah dibuat sesuai dengan yang diinginkan. UAT dilakukan dengan melakukan survei kepada calon pengguna sistem dan ahli. UAT terdiri dari 8 statement yang berasal dari penelitian Prawira, dkk. (2015). Pendapat dari responden diukur menggunakan 5 skala likert mulai dari sangat tidak setuju (1); tidak setuju (2); cukup (3); setuju (4); dan sangat setuju (5).

\section{E. Evaluation}

Tahap evaluation merupakan tahap evaluasi dari konten e-learning yang telah dibuat, proses evaluasi bertujuan untuk mengetahui e-learning telah sesuai dengan yang diinginkan oleh perusahaan. Proses evaluasi dilakukan menggunakan pengujian fungsionalitas sistem yang bertujuan untuk melihat fungsi dari fitur e-learning berhasil digunakan, pelaksanaan kuis dilakukan untuk melihat pengaruh sebelum dan sesudah menggunakan e-learning.

\section{Hasil dan Pembahasan \\ 3.1 Analyze}

Analyze merupakan tahap untuk mengidentifikasi kebutuhan e-learning. Pada tahap ini diidentifikasi mengenai cara karyawan mempelajari proses kegiatan pembuatan dan pemasangan kubah masjid, serta meneliti kebutuhan pekerja dalam menunjang dalam mempelajari proses kegiatan pembuatan dan pemasangan kubah masjid. Proses untuk mengidentifikasi kebutuhan perusahaan dilakukan dengan cara wawancara. Wawancara dilakukan kepada pekerja dan pemilik perusahaan sebagai ahli di perusahaan. Hasil wawancara kemudian diterjemahkan ke dalam voice of customer (VOC). Tabel 1 dan Tabel 2 menampillkan kondisi eksisting dan hasil identifikasi kebutuhan di perusahaan.

Berdasarkan Tabel 1, diketahui bahwa pekerja melakukan pembuatan dan pemasangan kubah masjid dengan cara berbeda-beda dan belum terstandarisasi, sehingga diperlukan SOP atau standar untuk pembuatan dan pemasangan kubah masjid. Selain itu perusahaan juga belum memiliki dokumen pembelajaran untuk pekerja yang masih belum memahami secara detail cara pembuatan dan pemasangan kubah masjid. Oleh karena itu, dibutuhkan suatu media pembelajaran yang dapat digunakan oleh pegawai untuk mempelajari proses pembuatan kubah masjid. Berdasarkan hasil wawancara tersebut, dapat disimpulkan bahwa penyediaan e-learning dengan konten yang berisikan proses pemasangan kubah masjid sesuai dengan SOP dapat menjawab kebutuhan pegawai.

Hasil dari identifikasi kebutuhan menunjukan bahwa pekerja membutuhkan e-learning yang menampilkan informasi dengan lengkap atau detail, 


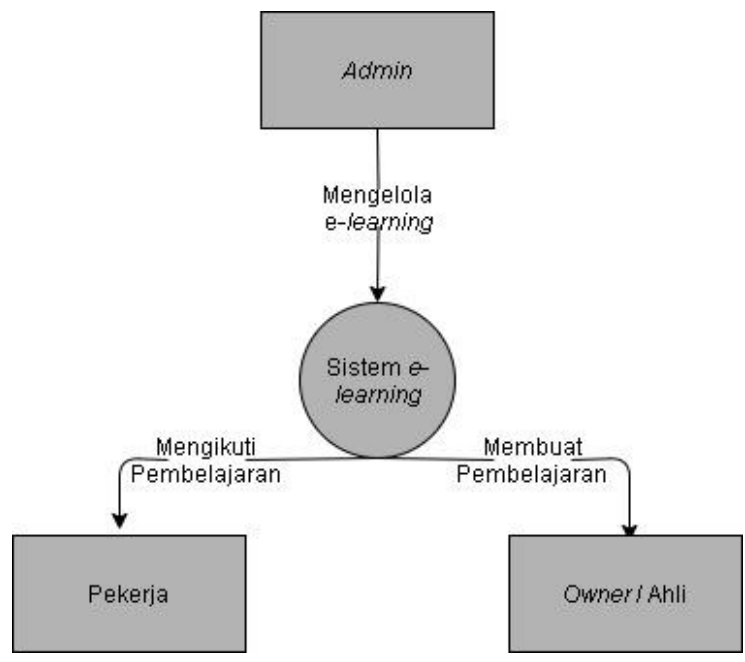

Gambar 1. Skema Belajar Menggunakan E-Learning

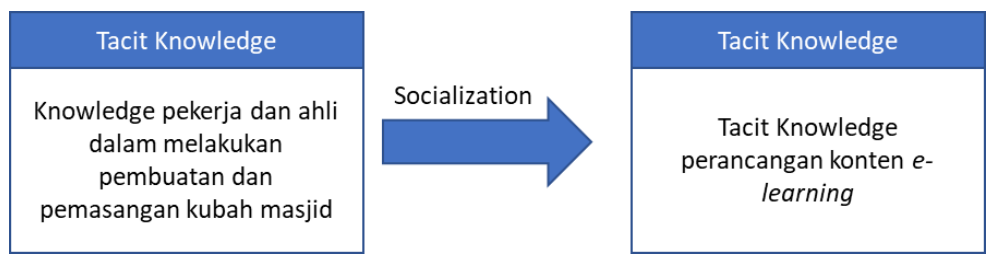

Gambar 2. Knowledge Conversion pada Socialization

Tabel 3. Identifikasi Proses, Alat, dan Bahan pada Pembuatan dan Pemasangan Kubah Masjid

\begin{tabular}{|c|c|}
\hline Kegiatan & Deskripsi \\
\hline Pembuatan Kerangka & $\begin{array}{l}\text { Pembuatan kerangka merupakan kegiatan awal dalam pembuatan dan pemasangan kubah masjid. } \\
\text { Pembuatan kerangka menggunakan bahan pipa galvanis ukuran } 1.5-2 \text { inch untuk rangka induk } \\
\text { dan ukuran } 3 / 4-1 \text { inch untuk rangka pembagi. Alat pembuatan menggunakan bending/ roll pipa. }\end{array}$ \\
\hline Pemasangan Kerangka & $\begin{array}{l}\text { Pemasangan kerangka adalah kegiatan tahap kedua dari pembuatan dan pemasangan kubah } \\
\text { masjid. Pemasangan kerangka merupakan proses pemasangan bahan yang telah dibentuk dan } \\
\text { dilakukan perakitan menjadi bentuk kubah masjid. Alat yang digunakan untuk kegiatan } \\
\text { pemasangan kerangka adalah mesin bor tangan dan mesin las. }\end{array}$ \\
\hline Pembuatan Daun Kubah & $\begin{array}{l}\text { Pembuatan daun kubah adalah tahap ketiga dari pembuatan dan pemasangan kubah masjid. } \\
\text { Pembuatan daun kubah menggunakan bahan Aluminum Composite Panel (APC), untuk alat } \\
\text { pembuatan daun kubah menggunakan gergaji tangan mesin. }\end{array}$ \\
\hline $\begin{array}{l}\text { Pemasangan Daun Kubah dan } \\
\text { Aluminum Foil }\end{array}$ & $\begin{array}{l}\text { Pemasangan daun kubah adalah tahap keempat dari pembuatan dan pemasangan kubah masjid, } \\
\text { tetapi sebelum melakukan pemasangan daun kubah, kerangka kubah harus dilapisi aluminum foil } \\
\text { terlebih dahulu untuk mencegah terjadinya kebocoran ketika hujan. Alat yang digunakan untuk } \\
\text { melakukan pemasangan daun kubah dan aluminum foil menggunakan mesin bor tangan. }\end{array}$ \\
\hline Pembuatan Plafon & $\begin{array}{l}\text { Pembuatan plafon adalah tahap kelima dalam pembuatan dan pemasangan kubah masjid. Plafon } \\
\text { dibuat dengan bahan seng plat gavallum, untuk alat menggunakan gunting seng biasa. }\end{array}$ \\
\hline
\end{tabular}

e-learning menampilkan tulisan dan gambar, $e$ learning mudah untuk digunakan, e-learning menampilkan informasi yang dapat dipercaya. Gambar 1 menampilkan skema pembelajaran menggunakan e-learning. Berdasarkan Gambar 1 terlihat bahwa proses bisnis e-learning terdiri dari admin sebagai pengelola $e$-learning, pekerja yang akan mengikuti pembelajaran, dan owner atau ahli yang akan menyusun konten pembelajaran.

\subsection{Design}

Pada tahap ini, dilakukan perancangan mengenai konsep dan juga konten untuk e-learning. Proses perancangan ini dilakukan dengan mengidentifikasi best practice pemasangan kubah masjid berdasarkan pengalaman pekerja. Proses identifikasi tersebut dilakukan dengan cara mengumpulkan tacit knowledge para pekerja untuk kemudian dikonversi dan digunakan sebagai panduan dalam merancang konten e-learning. Proses konversi tacit knowledge pemasangan kubah masjid dilakukan dengan menggunakan SECI yang terdiri dari tahap socialization, externalization, combination, dan internalization.

A. Socialization

Pada tahap ini dilakukan pengumpulan data dan proses konversi tacit knowledge. Gambar 2 menampilkan knowledge conversion pada tahap socialization. Eksplorasi knowledge terkait kegiatan pembuatan dan pemasangan kubah masjid dilakukan terhadap tiga aspek yaitu: 1) Identifikasi proses pembuatan dan pemasangan kubah masjid; 2) Identifikasi tahapan pembuatan dan pemasangan kubah masjid; dan 3) Identifikasi mesin dan bahan yang digunakan yang digunakan dalam pembuatan dan pemasangan kubah masjid. Tabel 3 menampilkan hasil eksplorasi pada proses pembuatan dan pemasangan, tahapan pembuatan, dan mesin serta bahan yang digunakan pada proses pembuatan dan pemasangan kubah masjid.

B. Externalization

Gambar 3 menampilkan knowledge conversion pada tahap externalization. Hasil eksplorasi yang telah diperoleh pada tahap socialization, kemudian 

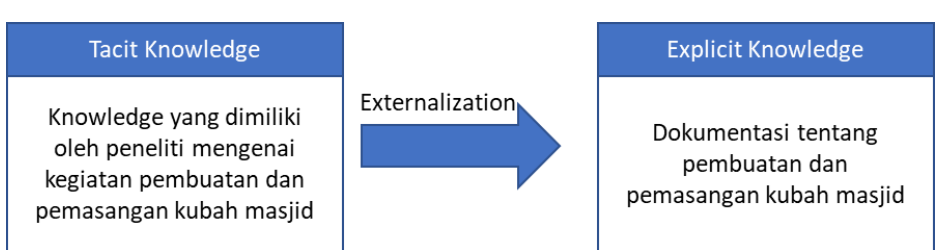

Gambar 3. Knowledge Conversion pada Externalization

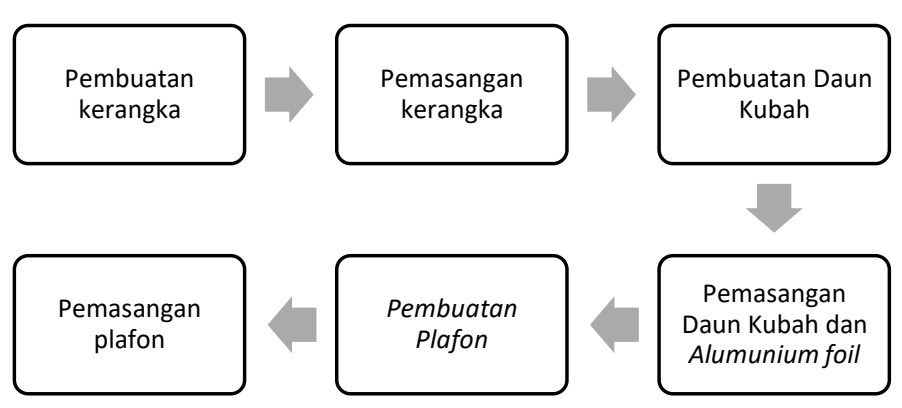

Gambar 4. Alur Kegiatan Pembuatan dan Pemasangan Kubah Masjid

\section{Kegiatan Pembuatan Kerangka Oleh Pekerja}

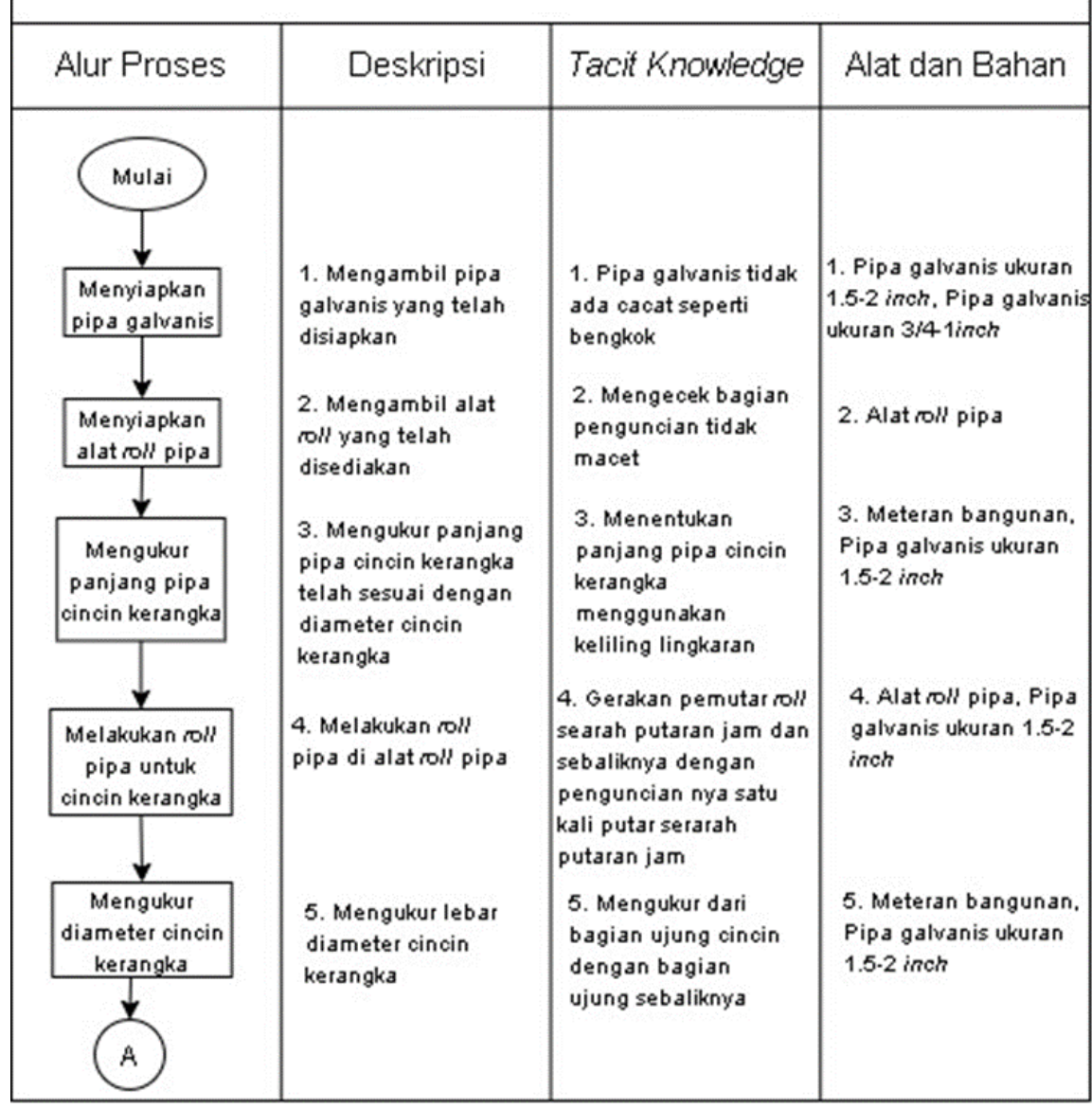

Gambar 5. Alur Proses Aktivitas Pembuatan Rangka oleh Pekerja

dituangkan dalam bentuk dokumen. Berdasarkan tahap socialization, alur proses pembuatan dan pemasangan kubah masjid yang terdiri dari 6 kegiatan. Kegiatan tersebut yaitu pembuatan kerangka, pemasangan kerangka, pembuatan daun kubah, pemasangan daun kubah dan aluminum foil, pembuatan plafon, dan terakhir pemasangan plafon. Gambar 4 menampilkan alur kegiatan pembuatan dan pemasangan kubah masjid. Lebih lanjut, pada penelitian ini dipetakan alur proses yang dilakukan oleh pekerja pada masing-masing kegiatan. Gambar 5 menampilkan alur proses untuk aktivitas pembuatan rangka.

\section{Combination}

Combinaton merupakan penggabungan proses dari awal sampai akhir yang dilakukan oleh pekerja dan ahli dalam kegiatan pembuatan dan pemasangan kubah masjid. Combination bertujuan untuk dapat menentukan alur proses terbaik dari kegiatan pembuatan dan pemasangan kubah masjid. Gambar 7 menampilkan knowledge conversion pada tahap combination. Pada tahap ini dilakukan brainstorming mengenai best practice pengerjaan masing-masing aktivitas. Output dari tahapan ini adalah panduan penyelesaian 6 aktivitas pada kegiatan pembuatan dan pemasangan kubah masjid. 


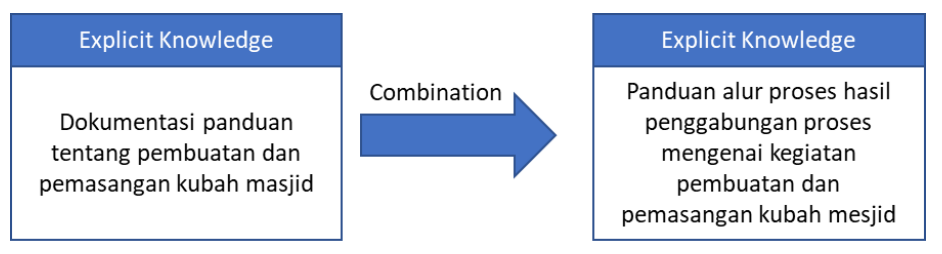

Gambar 6. Knowledge Conversion pada Combination

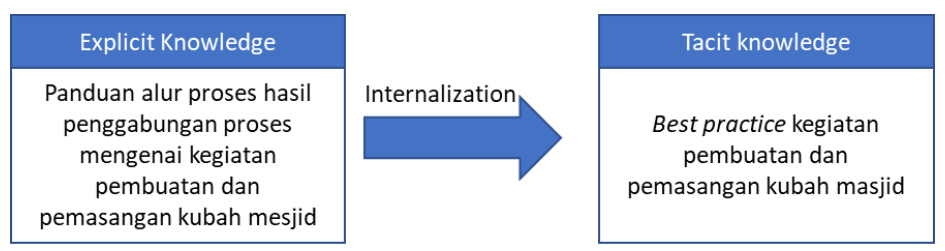

Gambar 8. Knowledge Conversion pada Combination

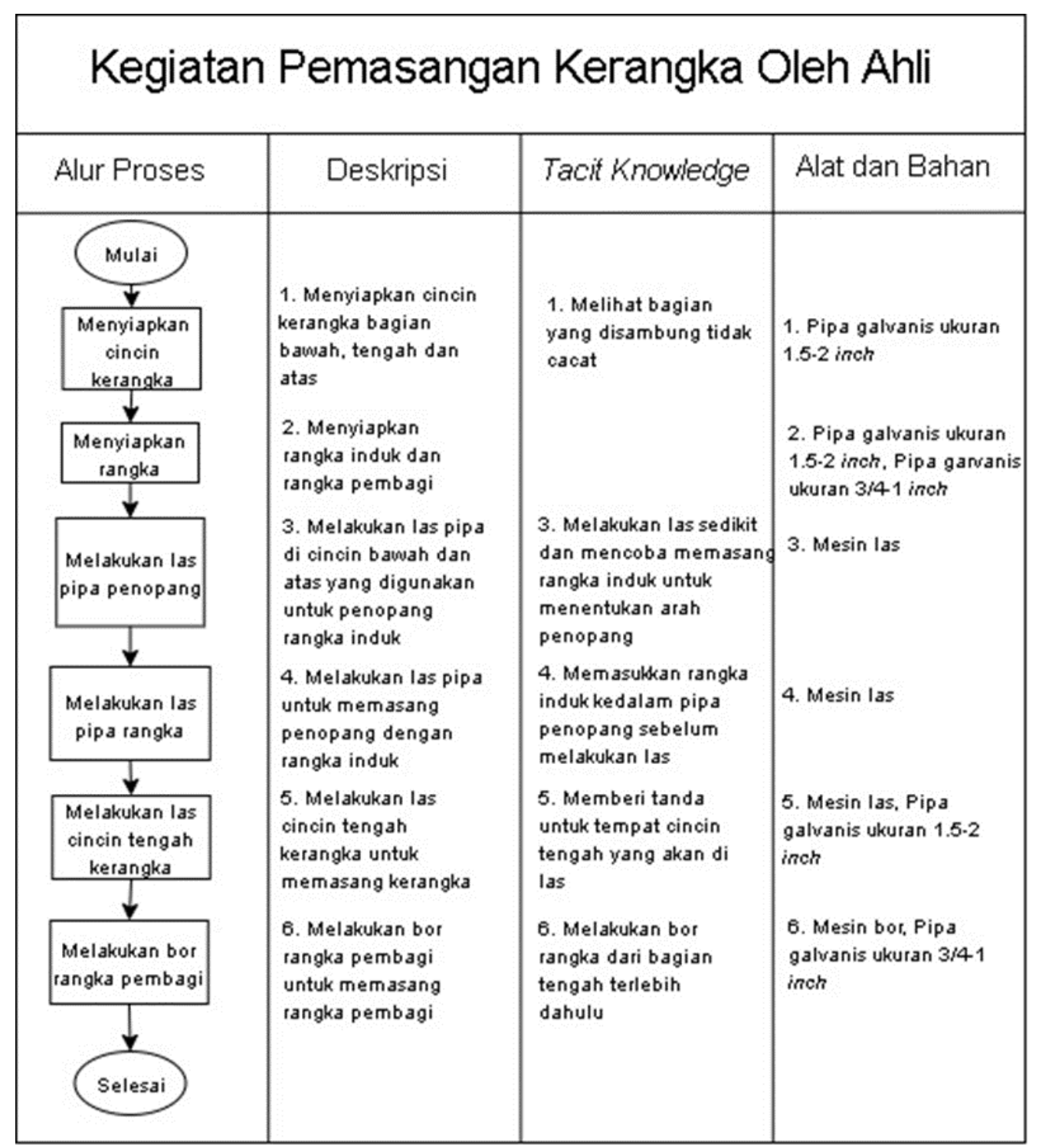

Gambar 7. Alur Proses Aktivitas Pembuatan Rangka oleh Ahli

Hasil brainstorming dapat dilihat pada Gambar 8.

D. Internalization

Pada tahap internalization dilakukan sosialisasi best practice mengenai kegiatan pembuatan dan pemasangan kubah masjid yang bertujuan untuk menyamakan pengerjaan terbaik pada kegiatan pembuatan dan pemasangan kubah masjid. Proses knowledge conversion pada tahap ini dapat dilihat pada Gambar 9.

\subsection{Development}

Pada tahap development, pembuatan e-learning menggunakan software Adobe Flash Professional CS6 dengan bantuan Adobe Flash Player 11 untuk menggunakan e-learning. Sebelum pembuatan $e$ learning, e-learning dirancang terlebih dahulu menggunakan storyboard berupa gambar sketsa memberikan gambaran awal pembuatan e-learning. Storyboard rancangan e-learning dapat dilihat pada Gambar 10. Setelah dilakukan perancangan terhadap storyboard, kemudian dilakukan perancangan terhadap e-learning. Terdapat tiga materi besar yang dapat dipelajari melalui e-learning, yaitu pembelajaran mengenai alur proses, bahan, dan alat. Selain itu, untuk mengevaluasi kemampuan pengguna sebelum dan setelah mempelajari materi melalui e-learning, terdapat menu kuis yang dapat diselesaikan oleh pengguna. Tampilan muka dari e-learning yang dirancang 


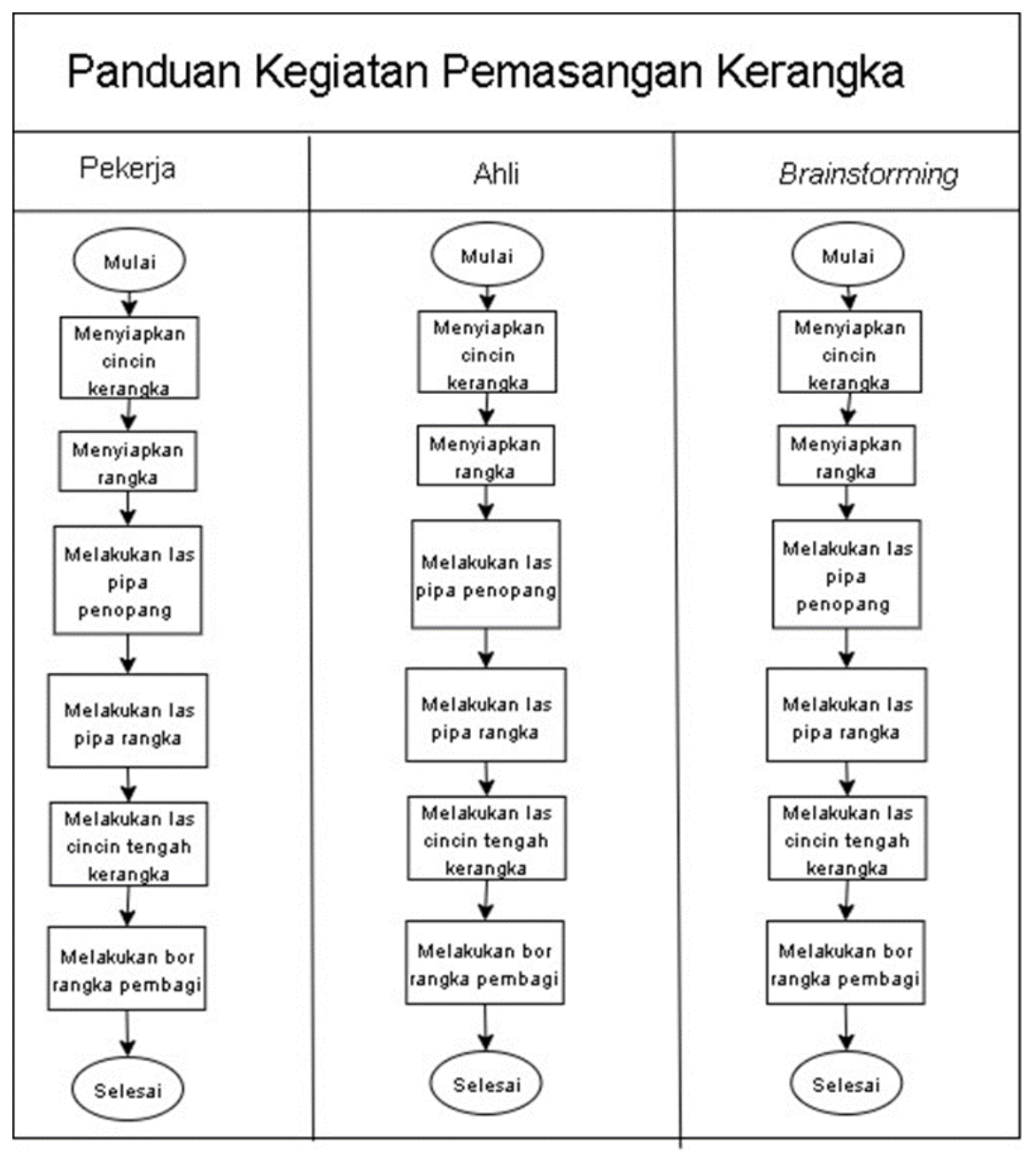

Gambar 8. Brainstorming Kegiatan Pemasangan Rangka

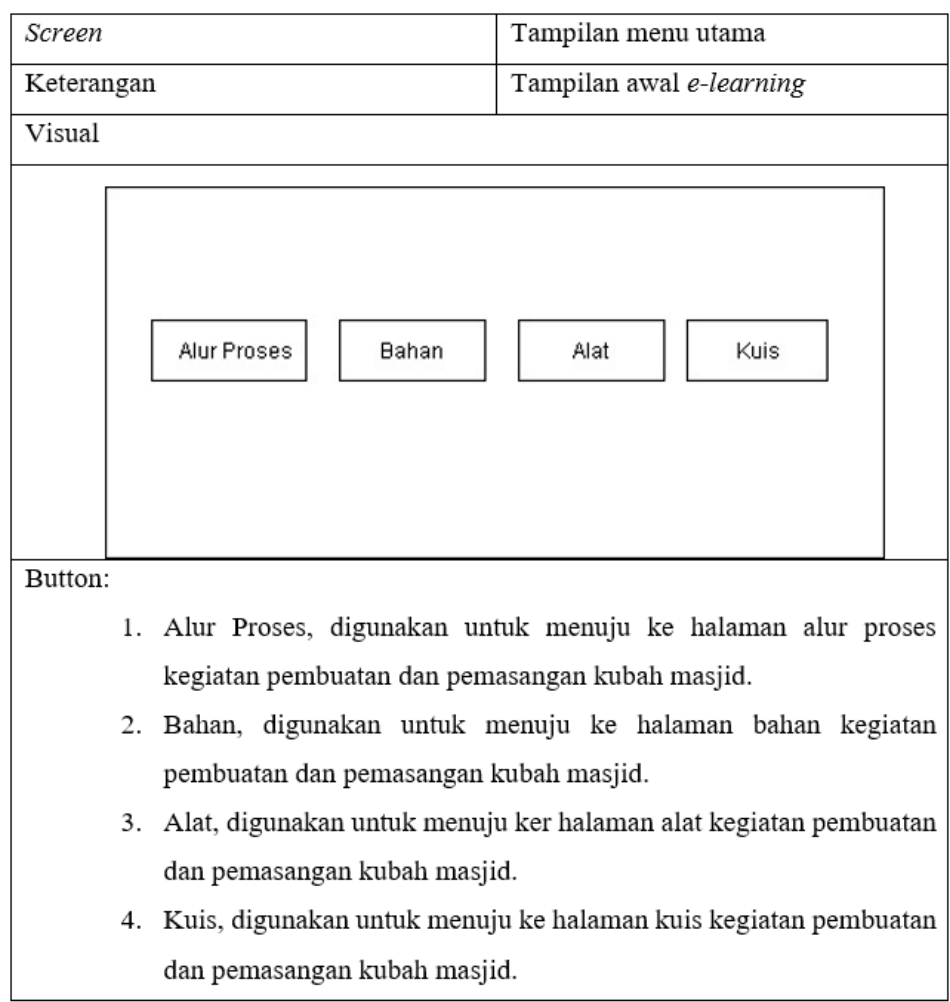

Gambar 9. Contoh Storyboard 


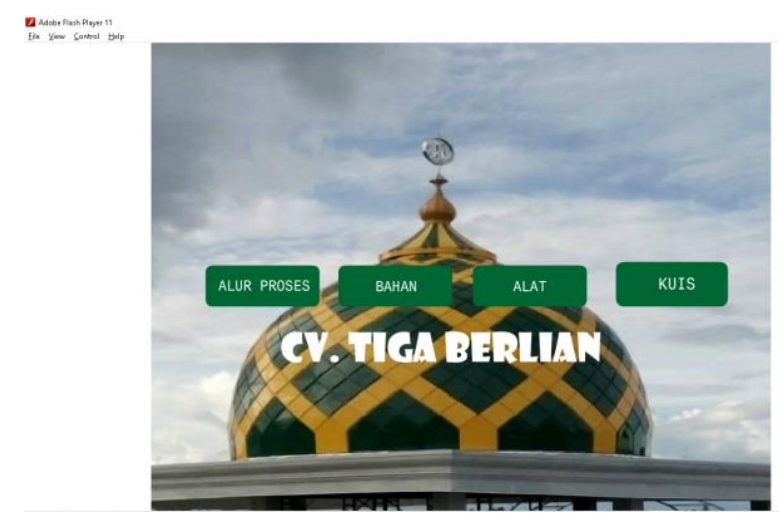

Gambar 10. Tampilan Menu Utama

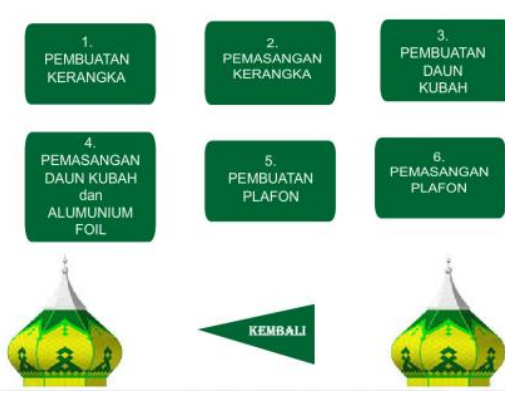

Gambar 11. Tampilan Alur Proses

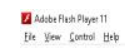
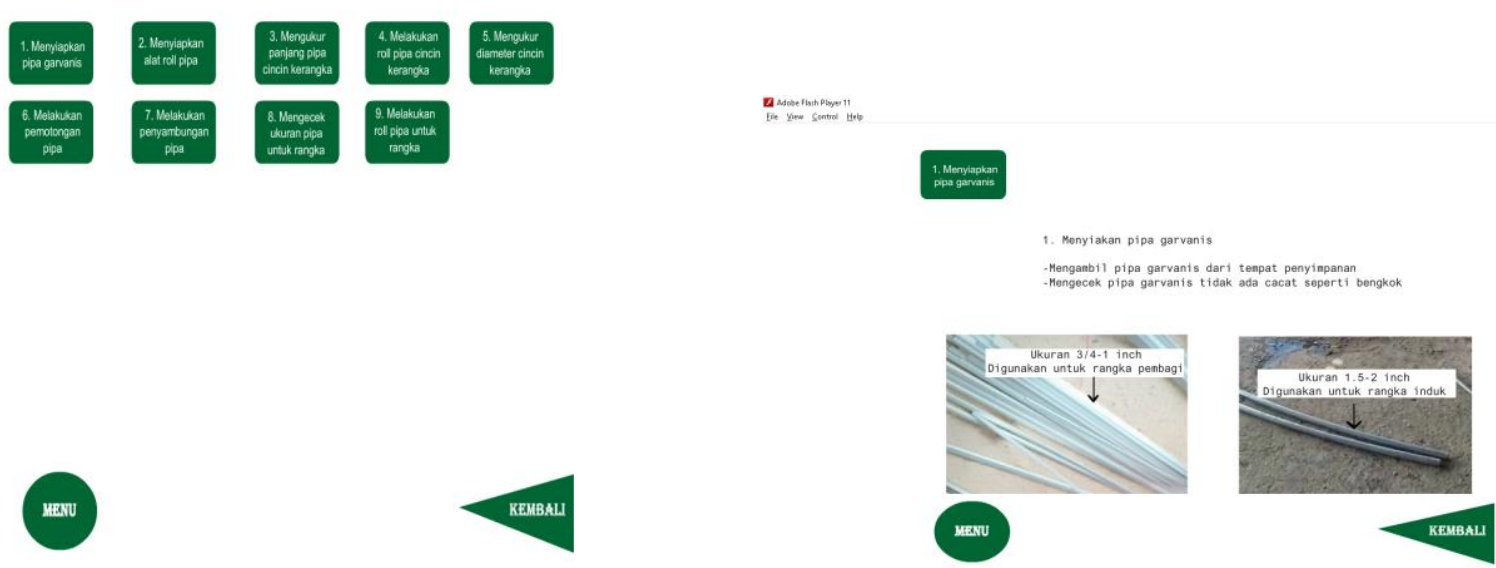

Gambar 12. Tampilan Menu Kegiatan

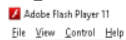

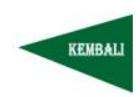

Gambar 13. Tampilan Detail Kegiatan
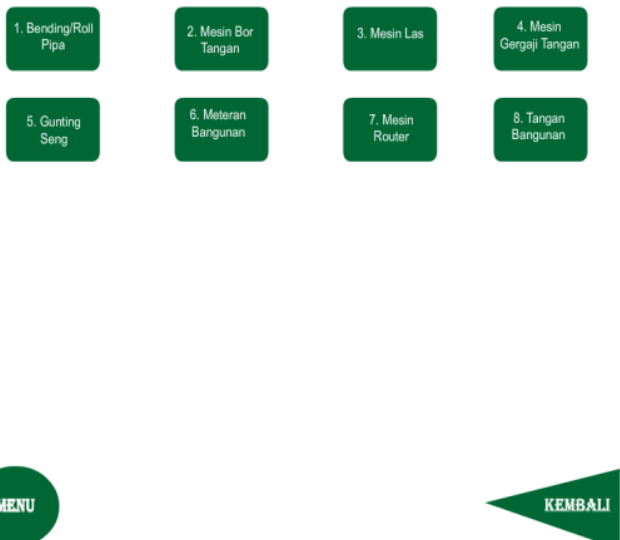

Gambar 14. Tampilan Menu Alat

ditampilkan pada Gambar 11-Gambar 15.

\subsection{Implementation}

Pada penelitian ini, tahap implementation berfokus pada percobaan penggunaan e-learning kepada pekerja mengenalkan konten e-learning yang telah dirancang dan melakukan pengujian penggunaan konten e-learning kepada pengguna. Proses percobaan dan pengujian dilakukan dengan memberikan demo aplikasi dan pengguna mencoba menggunakan sistem.
Selain itu, pada tahap ini pun dilakukan uji fungsionalitas dan user acceptance test kepada user.

A. Uji Fungsionalitas Sistem

Proses evaluasi dilakukan dengan menggunakan pengujian fungsionalitas sistem yang bertujuan untuk mengetahui perancangan konten e-learning kegiatan pembuatan dan pemasangan kubah masjid telah sesuai dengan yang diinginkan oleh perusahaan dan dapat digunakan dengan baik. Pengujian e-learning dilakukan terhadap fungsi 
Tabel 4. Hasil Uji Fungsionalitas

Fungsi Sistem

Status Pengujian

Menampilkan bagian yang dapat mengakses alur proses, bahan, alat, dan kuis.

Berhasil

Menampilkan bagian alur proses pembuatan dan pemasangan kubah masjid.

Berhasil

Menampilkan informasi bahan yang digunakan untuk pembuatan dan pemasangan kubah masjid

Menampilkan informasi alat yang akan digunakan untuk pembuatan dan pemasangan kubah masjid

Berhasil

Menampilkan kuis dari setiap kegiatan untuk menguji kompetensi pekerja.

Berhasil

Berhasil

Tabel 5. Hasil User Acceptance Test

\begin{tabular}{lcc}
\hline \multicolumn{1}{c}{ Pernyataan } & Respon \\
\cline { 2 - 3 } & Pekerja & Ahli \\
\hline Tampilan media e-learning ini menarik & 3 & 4 \\
Materi media e-learning ini mudah dipahami & 4 & 5 \\
Media e-learning membantu dalam pengembangan kemampuan & 4 & 5 \\
Media e-learning mudah untuk digunakan & 5 & 5 \\
Materi jelas untuk pengembangan kemampuan & 4 & 5 \\
Visual pada e-learning memudahkan memahami materi & 5 & 4 \\
Media e-learning sudah cukup baik & 5 & 5 \\
Media e-learning dapat dijadikan media bantu belajar & 5 & 5 \\
\hline
\end{tabular}

Tabel 6. Hasil Evaluasi Pembelajaran Menggunakan E-Learning

\begin{tabular}{|c|c|c|c|c|c|c|c|c|}
\hline \multirow{3}{*}{ Materi Kuis } & \multicolumn{8}{|c|}{ Nilai Kuis } \\
\hline & \multicolumn{2}{|c|}{ Pekerja 1} & \multicolumn{2}{|c|}{ Pekerja 2} & \multicolumn{2}{|c|}{ Non-Pekerja 1} & \multicolumn{2}{|c|}{ Non-Pekerja 2} \\
\hline & sebelum & sesudah & sebelum & sesudah & sebelum & sesudah & sebelum & sesudah \\
\hline Pembuatan Kerangka & 40 & 70 & 30 & 60 & 20 & 60 & 30 & 70 \\
\hline Pemasangan Kerangka & 30 & 80 & 40 & 80 & 10 & 70 & 10 & 80 \\
\hline Pembuatan Daun Kubah & 50 & 70 & 30 & 70 & 20 & 70 & 20 & 70 \\
\hline $\begin{array}{l}\text { Pemasangan Daun Kubah dan } \\
\text { Aluminum Foil }\end{array}$ & 20 & 60 & 20 & 60 & 30 & 60 & 20 & 60 \\
\hline Pembuatan Plafon & 30 & 70 & 40 & 80 & 20 & 80 & 30 & 60 \\
\hline Pemasangan Plafon & 40 & 80 & 30 & 70 & 30 & 80 & 10 & 80 \\
\hline Rata-rata & 35 & 71,7 & 31,7 & 70 & 21,7 & 70 & 20 & 70 \\
\hline
\end{tabular}

setiap fitur yang ada di dalam e-learning, untuk melihat e-learning dapat bekerja dan digunakan dengan baik. Pengujian fungsionalitas sistem $e$ learning kegiatan pembuatan dan pemasangan kubah masjid dilakukan pengujian kepada pekerja dan ahli. Setelah melakukan pengujian, didapatkan hasil dari pengujian fungsionalitas sistem kepada pekerja dan ahli bahwa fungsionalitas sistem $e$ learning berhasil bekerja dengan baik dan sesuai dengan yang diinginkan oleh perusahaan. Hasil uji fungsionalitas dapat dilihat pada Tabel 4.

B. User Acceptance Test

User acceptance test dilakukan untuk mengetahui kualitas e-learning kegiatan pembuatan dan pemasangan kubah masjid yang telah dibuat. Berdasarkan hasil UAT, baik dari sisi pekerja maupun ahli merasa bahwa rancangan e-learning yang dibuat sudah baik dari sisi tampilan, konten yang mudah dipahami, kemudahan untuk digunakan, kejelasan materi, visualisasi materi, dan kemampuan e-learning dalam membantu proses belajar. Hasil UAT dapat dilihat pada Tabel 5.

\subsection{Evaluation}

Proses evaluasi penggunaan e-learning dilakukan dengan cara pelaksanaan kuis yang telah disiapkan di dalam e-learning. Pelaksanaan kuis bertujuan untuk mengetahui kemampuan pekerja mengenai pembuatan dan pemasangan kubah masjid sebelum dan sesudah menggunakan e-learning. Pelaksanaan kuis akan dilakukan kepada 2 pekerja dengan tugas utama tidak di bagian pembuatan dan pemasangan kubah masjid dan kepada 2 non-pekerja. Tujuan pelaksanaan kuis kepada pekerja dengan tugas utama tidak di bagian pembuatan dan pemasangan kubah masjid adalah untuk mengetahui hasil pengujian kepada yang telah familiar dengan kegiatan pembuatan dan pemasangan kubah masjid. Sedangkan tujuan pelaksanaan kuis kepada non-pekerja adalah untuk mengetahui hasil pengujian kepada yang tidak familiar dengan kegiatan pembuatan dan pemasangan kubah masjid. Hasil evaluasi pembelajara menggunakan e-learning dapat dilihat pada Tabel 6.

\section{Kesimpulan}

Berdasarkan dari hasil penelitian yang telah dilakukan, didapatkan bahwa penelitian berkaitan dengan perancangan konten e-learning kegiatan pembuatan dan pemasangan kubah masjid. Perancangan konten e-learning menggunakan metode ADDIE dan metode SECI, metode ADDIE digunakan untuk pembuatan e-learning yang dibantu dengan 
metode SECI dalam pengumpulan data untuk konten $e$ learning. Proses kegiatan pembuatan dan pemasangan kubah masjid memiliki 6 kegiatan yaitu pembuatan kerangka, pemasangan kerangka, pembuatan daun kubah, pemasangan daun kubah dan aluminum foil, pembuatan plafon, dan pemasangan plafon.

Pada konten e-learning tidak hanya terdapat proses kegiatan pembuatan dan pemasangan kubah masjid, tetapi terdapat juga bahan yang akan digunakan, alat yang akan digunakan, dan kuis yang bertujuan sebagai evaluasi pemahaman materi dari konten e-learning. Pelaksanaan kuis dilakukan kepada 2 pekerja yang telah familiar dengan kegiatan pembuatan dan pemasangan kubah masjid dan kepada 2 non-pekerja yang tidak familiar dengan kegiatan pembuatan dan pemasangan kubah masjid. Hasil dari pelaksanaan kuis didapatkan bahwa terjadi peningkatan nilai dari sebelum menggunakan e-learning dan sesudah menggunakan e-learning. Secara praktis, hasil penelitian ini dapat membantu objek penelitian, yaitu Perusahaan Tiga Berlian dalam merancang konten pembelajaran berbasis elektronik untuk mempelajari proses pembuatan dan pemasangan kubah masjid. Secara teoritis, hasil penelitian ini memberikan contoh lain mengenai bagaimana metode ADDIE digunakan dalam perancangan konten e-learning. Lebih lanjut, penelitian ini pun memberikan gambaran mengenai bagaimana memperoleh rancangan konten e-learning dengan memanfaatkan model SECI untuk menggali best practice dalam suatu pelaksanaan aktivitas.

Terdapat beberapa keterbatasan pada penelitian ini. Pertama, knowledge yang dipertimbangkan pada penelitian ini murni merupakan knowledge dari para pekerja di perusahan. Pada penelitian ini tidak ikut dipertimbangkan tahapan-tahapan, maupun alat dan bahan yang digunakan oleh pihak eksternal (misal perusahaan lain ataupun pihak expertise di luar perusahaan). Untuk penelitian selanjutnya mungkin dalam proses perancangan konten e-learning dapat dikumpulkan juga data-data eksternal untuk kemudian dibandingkan dengan tahapan yang dijalankan di perusahaan. Berikutnya, pada e-learning yang dirancang, pekerja dapat mempelajari mengenai bagaimana proses pembuatan dan pemasangan kubah masjid, serta alat-alat yang digunakan dari video, foto, maupun flow chart yang dimasukan ke e-learning. Belum ada animasi yang dapat mensimulasikan proses pembuatan dan pemasangan kubah dalam e-learning. Pada penelitian berikutnya dapat juga dirancang $e$ learning yang lebih interaktif.

\section{Daftar Pustaka}

Adeyinka, T., \& Mutula, S. (2010). A proposed model for evaluating the success of WebCT course content management system. Computers in Human Behavior, 26(6), 1795-1805. https://doi.org/10.1016/j.chb.2010.07.007

Allen, W. C. (2006). Overview and Evolution of the ADDIE Training System. Advances in Developing Human Resources, 8(4), 430-441.
Battistuti, O. C., \& Bork, D. (2017). Tacit to explicit knowledge conversion. Cognitive Processing, 18(4), 461-477.

Bhuasiri, W., Xaymoungkhoun, O., Zo, H., Rho, J. J., \& Ciganek, A. P. (2012). Critical success factors for e-learning in developing countries: A comparative analysis between ICT experts and faculty. Computers and Education, 58(2), 843855.

Gaghman, A. A. (2019). The Impact of Knowledge Behavioural Factors on Tacit Knowledge Retention: Empirical Study in Oil and Gas Industry. Economies of the Balkan and Eastern European Countries, KnE Social Science, (pp. 34-53).

Iskandar, A., \& Subekan, A. (2018). the Pengaruh Personal Knowledge, Job Procedure Dan Technology Terhadap Kinerja Pegawai Organisasi Publik. JRMSI - Jurnal Riset Manajemen Sains Indonesia, 9(2), 168-192.

Jefri, R., Slamet, L., \& Huda, Y. (2018). Analisis Penerimaan Implementasi Sistem Informasi Elearning Universitas Negeri Padang Menggunakan Pendekatan Technology Acceptance Model. Jurnal Vokasional Teknik Elektronika \& Informatika, 6(1).

Kusumastuti, D., Soesanto, R. P., Kurniawati, A., \& Kurniawan, M. T. (2020). E-learning Content Design using ADDIE and SECI: Case of Shelving Activity in Research Organization. International Journal on Advanced Science Engineering Information Technology, 10721077.

Nonaka, I. (1991). The knowledge-creating firm. Harvard Business Review, December 1991, 162-171.

Nugraha, N. W., Kurniawati, A., \& Yunan, U. (2015). The Design Of Best Practice On The Media Transfer Activities And Preservation Based On Knowledge Conversion With SECI Method. Proceeding of Industrial Engineering and Service Science, September, 546-551.

Rizana, A. F., Hediyanto, U. Y. K. S., Ramadhan, F., \& Kurniawati, A. (2020). E-learning success determinants in higher education: A systematic literature review from users' perspective. IOP Conference Series: Materials Science and Engineering, $830(3)$. https://doi.org/10.1088/1757899X/830/3/032012

Wiphasith, H., Narumol, R., \& Sumalee, C. (2016). The Design of the Contents of an e-Learning for Teaching M.5 English Language Using ADDIE Model. International Journal of Information and Education Technology, 6(2), 127-131.

Xue, C. T. (2017). A Literature Review on Knowledge Management in Organizations. Research in Business and Management, 4(1), 30-41. 